\title{
Justice in anthropological theory and practice
}

\begin{abstract}
The purpose of the article is to prospectively describe the relationship between anthropological practice, public policy and the conception of justice. To this end, justice is seen as an experience of otherness, since analysis and possible responses in the context of institutional action must first focus on the meanings and representation that occur in the discourses and actions of the persons who are victims of state violence; anthropological methods and techniques must also be directed to understanding the dynamics of such violence in order to ultimately transform the conceptualization and practices of public policies.
\end{abstract}

Volume 3 Issue 5 - 2019

\author{
Alejandro Ernesto VÃizquez MartÃnez

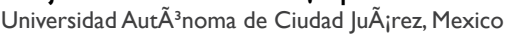 \\ Correspondence: Alejandro Ernesto VÃ $i z q u e z$ Mart $\tilde{A}\urcorner n e z$, \\ Universidad Aut $\tilde{A}^{3}$ noma de Ciudad JuÃ $i r e z$ Edificio J, cub $\left.\tilde{A}\right\urcorner c u l o$ \\ I 12, Her $\tilde{A}^{3}$ ico Colegio Militar, s/n Chamizal, Cd. JuÃ $i r e z$ \\ Chihuahua, Mexico, Tel 688-2100, ext. 3456 \\ Email alejandro.vazquez@uacj.mx
}

Received: August 03, 2019 | Published: September 18, 2019

\section{Anthropology, otherness and public policy}

The exercise of anthropology - in Mexico - had never had the challenge of the dimensions and characteristics it currently faces. The copious production of anthropological studies from ethnohistory, linguistics, ethnology and archaeology, until recent years, did not have to involve its methods and techniques with the implementation of public policies aimed at the humanitarian crisis and human rights that currently characterizes the country. Research designs in the field of anthropology have been distinguished from responding, from what has been called the "academy", to social problems throughout its range, using medium-scope theories and, where appropriate, structural explanations. Always, one way or another, in that path, the core of anthropological analyses and explanations is otherness.

It is nothing new that these studies address the difference from identity, that it is carefully observed what constitutes it and, fundamentally, how it is articulated with hegemonic identities. What is currently relevant relates to otherness in the context of public policy. On the one hand, the anthropological methodology has commonly been used in the development of State policy plans and programs, and has even been used, as is known, to the detriment of the groups that have been the subject of such interventions, on the other hand, such interventions methodology has been intended to unravel the meanings that make up the worldviews to articulate them to institutional practices and discourses with the intention of homogenizing diversity in the direction of the dominant conceptions, of which some aspects of legal anthropology bear witness.

Today, however, state policies have implicitly incorporated an understanding of otherness in order to seek justice. This intention has two initial interpretations. The first interpretation is understood from a socio-historical conception since without the legislation that has currently been prosecuted in Mexico, the provision of justice was in no way linked to victim thought and less to government actions, however, with the General Law on Victims and the General Law on the Enforced Disappearance of Persons, Disappearance Committed by Individuals and the National System for the Search for Persons, mainly the figure of the victim acquires a centrality from which all its derivations are not yet visible. The second interpretation, a consequence of the first, states that social phenomena where there are victims of state violence will give rise to tactics and strategies that will one way or another find their demarcations in conceptions - typifications - Legal. In this context, anthropological practices and theories find at least three possible developments. In the first instance, in the dialectical sense that integrates practice and theory, the "access" to the "procuration" of justice must have as an empirical reference the citizens themselves, and of this, those who serve as a testimony of that violence.

The notion of justice must be conceived from the victims to the institutions. The active participation of victims in the formation of the contents of laws that declare as their purpose justice, truth, reparation and guarantees of non-repetition, does not necessarily guarantee, as is already observed in reality, access to justice, mainly because "justice, as an experience of absolute otherness, is nonpresentable, but it is the occasion of the event and the condition of history. A story certainly ignorable for those who think they know what they talk about when they use this word, whether it's social history, ideological history, politics, legal history, etc."' The second issue is linked to the real possibility of public policy implementation, namely that anthropological research derived from the needs indicated in institutional plans and programs is feasible, in other words, the ethical exercise of anthropological methods and techniques depends on policies fully achieving their objectives. And finally, in an integrated way to the last two developments, the application of the anthropological root methodology.

An exploration led by the end of justice, like any other exploration, dispenses with any positivist glimpses. The long tradition of public policies that tacitly or expressly employ that model is immersed in virtually all institutions, yet the "necessity" of victim-centered policies should not compromise the analysis critic of anthropologies. In fact, with all the difficulties involved, it is precisely the anthropological analysis from which the diagnosis of any public policy should originate, since the development of others depends on that stage of the policy cycle.

\section{Anthropology, community and human rights}

What is the relationship between anthropology and human rights? We find it appropriate to initiate this section with a question that is 
not only questioned by a relationship that has largely been explained through the (inconsistencies) of public policies, as well as by the categories that various areas of anthropology we have analyzed, in particular, the subject and the community, of course, in the context of state policies. The subject since the conception of human rights is not yet a clear category, let alone in consensus. Reyes Mate points out that "the real subject of human rights is the citizen, not the human being. But let us not forget that the citizen is a human birth to which the nation elevates him to the status of subject of rights". ${ }^{2}$ In the same vein, Höffe argues: "Human rights are therefore referred to the person simply as a person, while fundamental rights concern the person as a member of a particular public entity". ${ }^{3}$ The specificity of fundamental rights, then, is membership in a social-cultural and political group, a political community that defines social guidelines and, significantly, the descriptive and prescriptive (coercive) norms that regulate social life, however multiple belongings involve tensions and conflict over political communities of adscription. That is why we must not forget that the "empirical multiplicity of the population is converted into an identity through the mechanisms of representation". ${ }^{4}$

Fundamental rights are instituted mainly through their progressive institutionalization, where all political communities are represented in the institutional (inter)national discourse. The empirical reference then becomes evidence of institutional actions. Commonly, people's rights function as indicators of what is not guaranteed, and yet as a way of evidence the violent strategies that the state deploys beyond the violence that it has allowed for itself. In this context, anthropological practice will build its analyses of violence from power or the meanings and representations produced by victims and perpetrators from intersubjectivity will not be understandable. Particularly if social regulation admits, as it does, violent action: "Violence thus involves tacit consideration of values and purposes. Moreover, when we talk about violence it is involved, perhaps because it fully participates in the mastery of meaning, an inescapable sense, parasite: the force that accompanies every area of regulation, every network of rules". ${ }^{5}$ This regulation, which is only feasible when the individual (and the State) are already "under the sign of separation and autonomy within their own confines", ${ }^{6}$ allows to understand the processes of intersubjectivity that occur in the dynamics where it is forced the subject to decipher himself with regard to what is forbidden, evidently in reference to the transgression of the rule, however, this mechanism now seems to be replicated with the victims from resilience: "Subjects who are able to secure themselves pose a minor threat to themselves and, being so, are not a threat to the governance capacities of States [...]. In that sense, the subject in resilience, is a subject who must fight permanently to accommodate the world. He is not a political subject who conceives changing the world, its structure and its conditions of possibility in order to ensure it, but a subject who accepts the disastrous character of the world in which he lives as a condition to be a part of it". ${ }^{\text {? }}$

In this context, anthropological practice becomes a powerful tool that allows intersubjective processes to be articulated with government devices, particularly in the transformation of designs and policy implementations public areas in general and justice-related policies, in particular.

\section{Conclusion}

If justice is an experience of absolute otherness, anthropological methodologies aimed at understanding the representations and social meanings linked to people who are victims of state violence work not only for the analysis of intersubjectivity as a central element in the construction of the sense of sociocultural meanings, are also the possibility of transforming the positivist conceptions of public policies that have now focused their intervention on the figure of the Victim. However, the inclusion of the various communities where strategies that seek to make absence in the pursuit of justice occur is not yet a reality. Institutional mechanisms are still conceived on individuality rather than social bonding and, consequently, tend to "hide" the structural conditions where violence occurs, as well as the responsibility of the State. However, we believe that it is possible to transform the relations between citizenship and state precisely through a type of public policy that practices actions focused on understanding otherness, that is, the ability to convert into action which derives from social dynamics. Even when such action is part of that dynamic.

\section{Acknowledgments}

None.

\section{Conflicts of interest}

The author declares no conflicts of interest.

\section{Funding}

None.

\section{References}

1. Derrida J. Fuerza de ley. El fundamento místico de la autoridad. Madrid: Tecnos; 2010. 64 p.

2. Mate R. Justicia de las víctimas. Terrorismo, memoria, reconciliación. España: Anthropos; 2008. 70 p.

3. Höffe O. Derecho intercultural. Barcelona: Gedisa; 2000. 168 p.

4. Hardt M, Negri T. La multitud y la guerra. México: Era; 2007. 66 p

5. Mier R. Notas sobre la violencia: las figuras y el pensamiento de la discordia. In: M Jiménez, editor. Subersión de la violencia. México: Casa Juan Pablo/UNAM; 2007. 98 p.

6. Esposito R. Diez pensamientos acerca de la política. Argentina: Fondo de Cultura Económica; 2012. 280 p.

7. Evans B, Reid J. Una vida en resiliencia. El arte de vivir en peligro. México: Fondo de Cultura Económica; 2016. 112-113 pp. 